\title{
HowULearn and Oodikone as tools for enhancing learning and progress in academic studies
}

\section{Kymäläinen, Hanna-Riitta}

IATED Academy

2019

Kymäläinen , H-R , Luukkainen , M \& Södervik , I 2019 , HowULearn and Oodikone as tools for enhancing learning and progress in academic studies . julkaisussa L Gómez Chova , $A$ López Martínez \& I Candel Torres (toim), EDULEARN19 Proceedings . EDULEARN Proceedings , IATED Academy , Sivut 1033-1037 , EDULEARN19: 11th annual International Conference on Education and New Learning Technologies , Palma de Mallorca, Espanja , 30/06/2019.

http://hdl.handle.net/10138/305893

publishedVersion

Downloaded from Helda, University of Helsinki institutional repository.

This is an electronic reprint of the original article.

This reprint may differ from the original in pagination and typographic detail.

Please cite the original version. 


\title{
HOWULEARN AND OODIKONE AS TOOLS FOR ENHANCING LEARNING AND PROGRESS IN ACADEMIC STUDIES
}

\author{
H.-R. Kymäläinen, M. Luukkainen, I. Södervik \\ University of Helsinki (FINLAND)
}

\begin{abstract}
New tools for examining and enhancing learning and progress in academic studies as well as for the quality management of teaching have been developed at the University of Helsinki, Finland. HowULearn is a digital, web-based reflection and feedback questionnaire that gives information on the studies of students and teaching in different sciences, Faculties and degree programmes. Students are encouraged to reflect on the results, and the programme's steering group utilizes the information in developing the programme and its teaching. The Oodikone [Oodi machine] tool collects and analyses data from students and student groups, as well as studies and courses, and the knowledge gained can then be utilized by the steering groups, as well as by PSP (personal study plan) councellors. In this presentation the HowULearn questionnaire and Oodikone will be presented, along with examples of the HowULearn data from a BSc degree in Agricultural Sciences. According to the preliminary results of the HowULearn questionnaire, the first-year students' approach to learning was mainly a deep-oriented, deep approach to learning. An organized study orientation correlated positively with self-efficacy beliefs, while a surface approach correlated negatively with self-efficacy. In addition, students' opinions related to the constructiveness of feedback received during the first study year correlated with their study success. A deep approach to learning and an organized study orientation also correlated positively with study-related exhaustion. Female students reported significantly higher study-related exhaustion and interest in their studies compared with male students. Based on the Oodikone data, four fictitious types of study progress (credit accumulation) were indicated. The data also shows that students can be rewarded and offered help, and single courses and bottlenecks in the degree programme can be improved. Shared faculty-level rules can support a degree programme and its steering group.
\end{abstract}

Keywords: Higher education, quality management, progress, student, study, skills, course, guidance

\section{INTRODUCTION}

University students' perceptions of learning, their self-efficacy beliefs and possible exhaustion can all affect the progress and success of studies. On the other hand, learning is also an academic skill that a student can develop. For this reason, new tools for examining and enhancing learning and progress in academic studies as well as for the quality management of teaching have been developed at the University of Helsinki, Finland. Two tools, the HowULearn questionnaire and Oodikone ["Oodi machine"] are presented here, including examples from the HowULearn data of a BSc degree of Agricultural Sciences.

HowULearn is a digital, web-based reflection and feedback questionnaire [1]. The aim of the system is to obtain information on students' studies and teaching in different sciences, Faculties and degree programmes. At the individual level, the tutoring system "supports student learning by giving individual-level feedback on studying", while the programme level provides reports which can be used to enhance teaching. At the institutional level, it can be used for quality enhancement [1]. The online software program of the HowULearn questionnaire was developed in 2012, although the questionnaire had already been used in 2006 in the Faculty of Veterinary Medicine [2]. Several studies have been published concerning the results of the HowULearn questionnaire and its preceding versions (Table 1). 
Table 1. Studies on the HowULearn questionnaire and its earlier versions (Learn, the Experience of Teaching and Learning Questionnaire ETLQ).

\begin{tabular}{|c|c|c|c|}
\hline $\begin{array}{l}\text { Reference } \\
\text { and } \\
\text { publication } \\
\text { year }\end{array}$ & Questionnaire & Sample & Focus \\
\hline [3] 2010 & $\begin{array}{l}\text { A revised version } \\
\text { of the ETLQ }\left(^{* *}\right)\end{array}$ & $\begin{array}{l}\text { Students of ten Faculties (incl. } \\
\text { Agriculture and Forestry), study } \\
\text { years I and III ( } n=2509)\end{array}$ & Approaches to learning \\
\hline [4] 2010 & $\begin{array}{l}\text { A modified version } \\
\text { of ETLQ }\left({ }^{*},{ }^{* *}\right)\end{array}$ & $\begin{array}{l}\text { Veterinary students, study year } \\
\text { III }(n=36),(\text { an extension of [3]) }\end{array}$ & $\begin{array}{l}\text { Approaches to learning, } \\
\text { perceptions of the teaching- } \\
\text { learning environment, study } \\
\text { success }\end{array}$ \\
\hline [5] 2011 & $\begin{array}{l}\text { A modified version } \\
\text { of } \operatorname{ETLQ}\left({ }^{*},{ }^{* *}\right)\end{array}$ & $\begin{array}{l}\text { Students of the Faculties of } \\
\text { Law, Pharmacy and Veterinary } \\
\text { Medicine, study year I }(n=426)\end{array}$ & $\begin{array}{l}\text { Perceptions of the teaching- } \\
\text { learning environment }\end{array}$ \\
\hline [6] 2012 & $\begin{array}{l}\text { Learn }\left({ }^{*},{ }^{* *}\right)(\text { same } \\
\quad \text { as in [4], [5], [7]) }\end{array}$ & - & $\begin{array}{c}\text { Explanation and discussion of } \\
\text { the Learn tool }\end{array}$ \\
\hline [7] 2012 & $\begin{array}{l}\text { A modified and } \\
\text { shortened version } \\
\text { of ETLQ }\left({ }^{*},{ }^{* *}\right)\end{array}$ & $\begin{array}{l}\text { Bioscience students, study } \\
\text { year I }(n=188)\end{array}$ & $\begin{array}{l}\text { Perceptions of teaching- } \\
\text { learning environment, } \\
\text { approaches to learning, study } \\
\text { success, factors enhancing or } \\
\text { impeding studying }\end{array}$ \\
\hline [8] 2013 & $\begin{array}{l}\text { A modified version } \\
\text { of ETLQ }\left({ }^{* *}\right)\end{array}$ & $\begin{array}{c}\text { Finnish ( } n=2509 \text {, ten Faculties, } \\
\text { study years I and III) and } \\
\text { British ( } n=2710, \text { four subject } \\
\text { areas, early and late in studies) } \\
\text { students }\end{array}$ & $\begin{array}{l}\text { Experiences of teaching- } \\
\text { learning environment, } \\
\text { approaches to learning; } \\
\text { validation of the ETLQ tool }\end{array}$ \\
\hline [9] 2014 & $\begin{array}{l}\text { A modified version } \\
\text { of ETLQ }\left({ }^{* *}\right)\end{array}$ & $\begin{array}{l}\text { Students of the Faculty of } \\
\text { Biological and Environmental } \\
\text { Sciences, study years I and III } \\
(n=103)\end{array}$ & $\begin{array}{l}\text { Changes in approaches to } \\
\text { learning and in students' } \\
\text { experiences of the teaching- } \\
\text { learning environment, study } \\
\text { success }\end{array}$ \\
\hline [10] 2014 & Learn & $\begin{array}{l}\text { Students of the Faculty of Arts } \\
\text { and Humanities, study year II } \\
\qquad(n=93)\end{array}$ & $\begin{array}{l}\text { Experiences of enhancing } \\
\text { and impeding factors, } \\
\text { approaches to learning, study } \\
\text { progress }\end{array}$ \\
\hline [2] 2017 & HowULearn & $\begin{array}{c}\text { Finnish }(n=109) \text { and Italian } \\
(n=112) \text { veterinary students, } \\
\text { study years I and III }\end{array}$ & $\begin{array}{c}\text { Evaluation of the tool from a } \\
\text { quality assurance point of } \\
\text { view }\end{array}$ \\
\hline
\end{tabular}

*In [10] Learn was referred to as being the method used in [6]. Based on this information, the ETLQ used in other studies is marked with *.

${ }^{* *}$ In [2] HowULearn was first mentioned with that name, but referred to as the same method used in earlier studies, marked with **.

The Oodikone tool has been developed at the University of Helsinki, in the Department of Computer Science, over several years, and is intended for analysing student and study data [11]. Data is collected from students and student groups, as well as studies and courses. The data is based on the data of a study register system Oodi. In Oodikone, several filters can be used, such as the number of credits (ECT) or the student's presence or absence. Since autumn 2018 the Oodikone system has been being piloted by all the degree programmes of the University of Helsinki. The basic principles of 
the system are user orientation, agile development, independency and data security [11]. The data security rules for students are available on the Internet [12]. Published research articles of this recently-developed tool were not available, which is one reason why this study was undertaken.

\section{METHODOLOGY}

An example of HowULearn results is presented below using the data of a survey from the BSc programme in Agricultural Sciences at the end of the first study year (spring 2018). A total of 49 firstyear students (female $n=27$; male $n=22$ ) with Agricultural Sciences as their major completed the online questionnaire in April 2018. Informed consent was obtained from the participants. The questionnaire contained 49 Likert-scale items measuring students' perceptions of their teaching-learning environment, their approaches to learning, their self-efficacy beliefs and their study-related interest and exhaustion. Students' study success was measured via the average score of all credits gained during the first study year. Statistical analyses were accomplished with IBM SPSS Statistics 25 (IBM, Armonk, NY).

Fictitious examples are presented below to illustrate the Oodikone data. The four student cases A-D in the example are not real because the Oodikone data is confidential, but they reflect the general features of some possible types of study paths. The examples were produced with Excel.

\section{RESULTS}

\subsection{HowULearn}

Preliminary results from the HowULearn questionnaire revealed that the first-year students' approach to learning was mainly deep-oriented. A deep approach to learning and and organized study orientation correlated positively with self-efficacy beliefs $(r=.55, p<.00 ; r=.41, p=.0034)$, whereas a surface approach correlated negatively with personal self-efficacy $(r=-.63, p<.00)$.

Students' opinions relating to the constructiveness of feedback received during the first-study year correlated with their study success $(r=.283, p=.049)$. However, students' responses to a single item that measured whether they had received enough feedback from the teachers, indicated that, in general, students would like to receive more feedback ( $M=2.76 / 5.00 ; S D=.90)$.

A deep approach to learning and an organized study orientation correlated positively with studyrelated exhaustion $(r=.66, p<.00 ; r=.42, p=.002)$. The female students reported significantly higher exhaustion than the male students $(t(47)=-2.97, p=.005)$, but also a significantly higher interest in their studies $(t(47)=-2.19, p=.033)$.

After receiving personal feedback from the questionnaire, the students were advised to recognize, reflect on and develop their own study skills, for example regarding portfolio work in the BSc programme. The first steps for using group-level information have been taken by the steering committee in the Agricultural Sciences. For example, some possible reasons for exhaustion were identified in discussions with the students, which led to some modifications being made to the study structure and model path. The questionnaire is tied to specific courses in the degree.

\subsection{Oodikone}

Figure 1 represents the study progress in terms of credits (ECTs) of four fictitious examples of firstyear students. All the students began their studies in autumn. Student $A$ seems to have made extremely efficient progress over the whole year. Student $B$ also gained credits over the whole study year but at a more modest rate than student $A$. Both students $A$ and $B$ exceeded the yearly 55 credit limit, which is the current desired study progress time per year according to the funding model of the University of Helsinki, as well as the respective desired time in the future model [13]. Student C made very modest progress at the beginning of the studies and over the whole study year. Student $D$ hardly gained any credits during the autumn term, but showed a modest increase in the second term. 


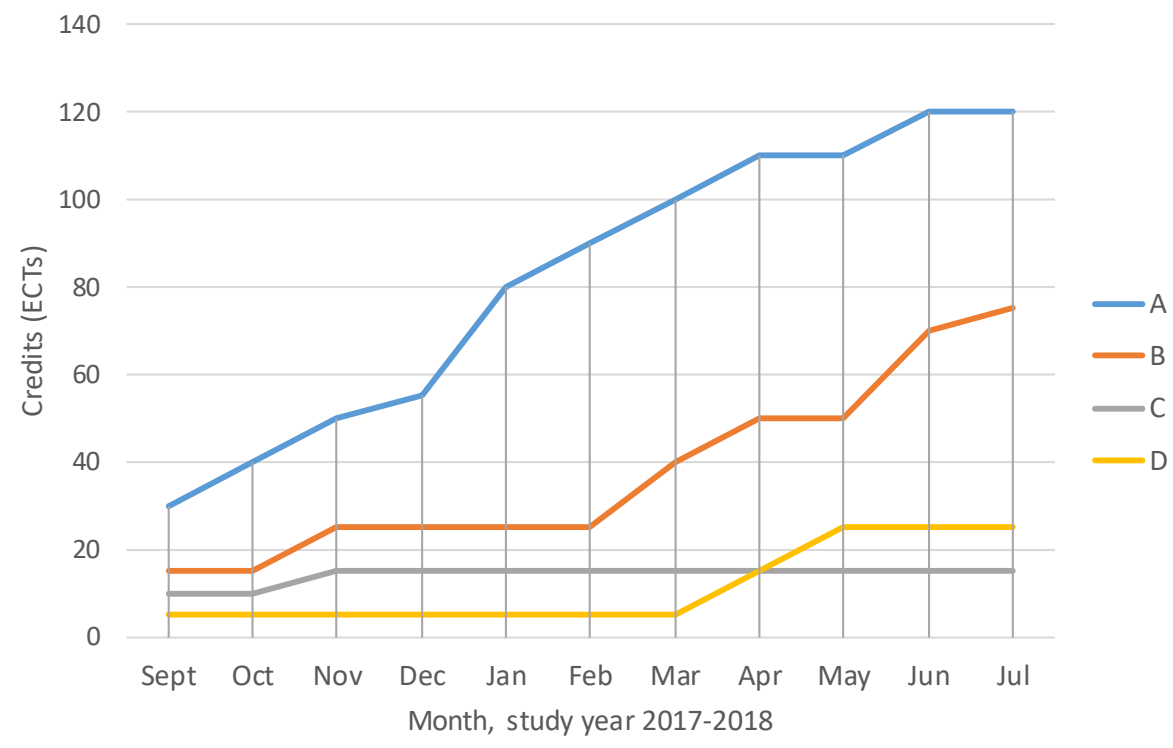

Figure 1. Fictitious model examples of the study progress of students A-D based on Oodikone data.

Practical measures based on the observations of these students could include the following. Student $A$ could be acknowledged for making good progress. Student B could be also commended because the yearly credits gained exceeded the recommended 55 credits. Student $C$ should be contacted and offered support, although the optimal time for making contact would have been earlier, either after observing the small slope in the study curve, or even more importantly, when there occurred a complete stop in studying. Student D should also have been contacted earlier, but it might still be beneficial to make contact at the end of the period.

With the help of the Oodikone data, the steering group of a BSc or MSc programme can follow the general progress of the studies of their students. The Faculty of Agriculture and Forestry in Helsinki is developing common criteria for the various study years for threshold values of credits within a certain time period in order to catch students in need of special attention. As an example, an advisory meeting could be offered by email to such students to discuss the situation and offer help. In addition, students who are making a good progress could be rewarded in some way. General rules such as these could help the programmes, teachers and study councellors to contact these students, acknowledge them or offer them help. The Faculties of Helsinki University differ from each other in these practices and the procedural details for utilizing Oodikone data vary.

\section{CONCLUSIONS}

The HowULearn questionnaire and the personal study plan (PSP) together give support and feedback to the students as they develop their scientific and study skills. The questionnaire is tied to specific courses in the degree, students are encouraged to reflect on the results, and the steering group utilizes the information in the development of the programme and teaching. Since no earlier published data of the HowULearn results in the Agricultural Sciences at Helsinki University was available, it was recognized that there was a need concerning this student group.

Oodikone is a very useful tool for quality management in academic degree programmes. The programme leaders and study councellors are able to follow the progress of studies of a study population as well as of individual students. Based on the data, students can be rewarded and/or offered help. In addition, single courses and bottlenecks in the programme can be improved. More qualitative data concerning the reasons for possible problems observed with the HowULearn and Oodikone tools in study progress, studying and wellbeing can be obtained, for example, through student interviews. These practical processes need still refining relating to, for example, motivation, more data and interpretation support as well as decision-making and the implementation of measures. Finally, common rules at the Faculty level could support degree programmes and their steering groups. 


\section{ACKNOWLEDGEMENTS}

Participation in the EDULEARN19 conference was funded by the "Opetuksen toteutuksen Digiloikka" [Implementing Digileap in Teaching] project by the University of Helsinki.

\section{REFERENCES}

[1] University of Helsinki, "HowULearn - a tool for learning", 2016. Retrieved from https://blogs.helsinki.fi/howulearn/en/

[2] M. Ruohoniemi, M. Forni, J. Mikkonen \& A. Parpala. "Enhancing quality with a research-based student feedback instrument: a comparison of veterinary students' learning experiences in two culturally different European universities", Quality in Higher Education, vol. 23, no. 3, pp. 249-263, 2017.

[3] A. Parpala, S. Lindblom-Ylänne, E. Komulainen, T. Litmanen \& L. Hirsto, "Students' approaches to learning and their experiences of the teaching-learning environment in different disciplines", British Journal of Educational Psychology, vol. 80, pp. 269-282, 2010.

[4] M. Ruohoniemi, A. Parpala, S. Lindblom-Ylänne \& N. Katajavuori, N., "Relationships between students' approaches to learning, perceptions of the teaching-learning environment, and study success: a case study of third-year veterinary students", Journal of Veterinary Medical Education, vol. 37, no. 3, pp. 282-288, 2010.

[5] A. Haarala-Muhonen, M. Ruohoniemi, N. Katajavuori \& S. Lindblom-Ylänne, "Comparison of students' perceptions of their teaching-learning environments in three professional academic disciplines: a valuable tool for quality enhancement", Learning Environments Research, vol. 14, pp. 155-169, 2011.

[6] A. Parpala \& S. Lindblom-Ylänne, "Using a research instrument for developing quality at the university", Quality in Higher Education, vol. 18, no. 3, pp. 313-328, 2012.

[7] H. Rytkönen, A. Parpala, S. Lindblom-Ylänne, V. Virtanen \& L. Postareff, "Factors affecting bioscience students' academic achievement", Instructional Science, vol. 40, pp. 241-256, 2012.

[8] A. Parpala, S. Lindblom-Ylänne, E. Komulainen \& N. Entwistle, "Assessing students' experiences of teaching-learning environments and approaches to learning: validation of a questionnaire in different countries and varying contexts", Learning Environments Research, vol. 16, pp. 201-215, 2013.

[9] H. Asikainen, A. Parpala, S. Lindblom-Ylänne, G. Vanthornout, \& L. Coertjens, "The development of approaches to learning and perceptions of the teaching-learning environment during Bachelor level studies and their relation to study success", Higher Education Studies, vol. 4, no. 4, pp. 24-36, 2014.

[10] T. Hailikari \& A. Parpala, "What impedes or enhances my studying? The interrelation between approaches to learning, factors influencing study progress and earned credits", Teaching in Higher Education, vol. 19, no. 7, pp. 812-824, 2014.

[11] University of Helsinki, "Oodikone. Helsingin yliopiston opiskelija- ja opintodatan analysointiväline" [An analysis tool of student and study data at the University of Helsinki], 2019. Retrieved from https://blogs.helsinki.fi/oodikone/ (in Finnish)

[12] University of Helsinki, "Data protection statement", 2018. Retrieved from https://guide.student.helsinki.fi/en/article/data-protection-statement

[13] Ministry of Education and Culture, "Luovuutta, dynamiikkaa ja toimintamahdollisuuksia. Ehdotus ammattikorkeakoulujen ja yliopistojen rahoitusmalleiksi vuodesta 2021 alkaen" [Creativity, dynamics and possibilities of means of action. A proposal of funding models of applied universities and universities from 2021], Opetus- ja kulttuuriministeriön julkaisuja [Publications of the Ministry of Education and Culture], no. 35, 2018. (in Finnish) 